\title{
"23 April National Sovereignty and Children's Day" led by kids of Asia Minor from historical, cultural, and scientific perspective
}

\author{
Mehmet Turgut ${ }^{1,2}$ \\ Published online: 8 May 2020 \\ (C) Springer-Verlag GmbH Germany, part of Springer Nature 2020
}

Around the globe, children who are the elderly of the future have been given importance since ancient times as they may sometimes play a vital role in the fate of their country, possibly by contributing to the development of the self-confidence of children, as did in the following story upon the institution of the 23rd of April to celebrate the children by Mustafa Kemal, also called Atatürk (Father of Turks) in Minor Asia.

\section{April National Sovereignty and Children's Day}

23 April National Sovereignty and Children's Day is one of the public holidays in Turkey. Mustafa Kemal Atatürk, the founder of the Turkish Republic, made April 23 as a gift to all the world's children because of their importance in our future (Fig. 1) (https://en.wikipedia.org/wiki/National Sovereignty_and_Children\%27s_Day).

During the War of Independence under Mustafa Kemal, the Turkish Grand National Assembly gathered in Ankara on April 23, 1920 (Fig. 2) (https://en.wikipedia.org/wiki/Grand National_Assembly_of_Turkey) and built the foundations of new, secular, independent, democratic, and contemporary Republic of Turkey from the Ottoman Empire [1-3]. After the defeat of the allied invasion forces in 1922 and the signature of the Peace Settlement of Lausanne in 1923, Ankara city was declared as the capital of the Republic of Turkey and Mustafa Kemal was elected as its first president [2]. On April 23, 1929, Atatürk dedicated the sovereignty day to all the children of the world because they are the safety of

Mehmet Turgut

drmturgut@yahoo.com

1 Department of Neurosurgery, Aydın Adnan Menderes University Faculty of Medicine, 09100 Efeler, Aydın, Turkey

2 Department of Histology and Embryology, Aydın Adnan Menderes University Health Sciences Institute, 09100 Efeler, Aydın, Turkey peace in the future (https://en.wikipedia.org/wiki/National Sovereignty_and_Children\%27s_Day). To the best of my knowledge, Turkey thus became the first country in the world that celebrates an official Children's Day.

\section{TRT International April 23 Children's Festival}

After 1929, the children in contemporary Turkey celebrated the "Sovereignty and Children's Day" every year; they participated the ceremonies in stadiums and indoor gyms with children from different countries of the world, the representatives of the children symbolically replaced with the positions of state officials, including the President and local governors, and they discussed various matters regarding problems of children (Fig. 3 and Cover) (https://www.trt23nisan.com/tr/tarihce/). Since 1979, the festival began to organize by Turkish Radio and Television (TRT) Corporation as International Children's Day on April 23 and many countries in the world sent their children to the national festivals in different cities of Turkey in a spirit of peace and harmony (Fig. 4) (https://www.trthaber.com/haber/turkiye/40ulkeden-800-cocuk-trtnin-duzenledigi-senlikte-bulustu-412004. html). And, UNICEF declared April 23 as the "International Children's Day" (https://en.wikipedia.org/wiki/National_ Sovereignty_and_Children\%27s_Day). Undoubtedly, this is a very important milestone for Turkish children to connect with the world's children and for cultural exchanges, resulting in a truly international assembly.

Today, the International 23 April Children's Festival organized by TRT in Turkey provides a unique opportunity for cultural and scientific collaboration of children in the world. Thus, it is certain that these children will play an important role in international cooperation and peace of their countries in the future. As clearly stated by Mustafa Kemal Atatürk: "Loving children is a necessity for humanism". Now we believe that our duty should be to raise our children with the awareness that today's children will be the elderly of the future. 
Fig. 1 A photograph of the President Atatürk, the founder of the Republic of Turkey, during the celebration for the Day of National Sovereignty on April 23, 1929 (https://en.wikipedia.org/ wiki/National Sovereignty and Children\%27s_Day)

Fig. 2 A photograph of the President Atatürk and his colleagues near the building in which the Grand National Assembly of Turkey was assembled in Ankara on April 23, 1920 following a meeting for the 7 th anniversary of the foundation of the Republic of Turkey in 1930 (https://en.wikipedia.org/wiki/ Grand_National_Assembly_of Turkey)

Fig. 3 and Cover A photograph of children from different countries of the world performing folk dance on the street in Ankara, Turkey, during the National Sovereignty and Children's Day, with written permission of the authority of the Turkish Radio and Television Corporation (https://www.trt23nisan.com/tr/ tarihce/)
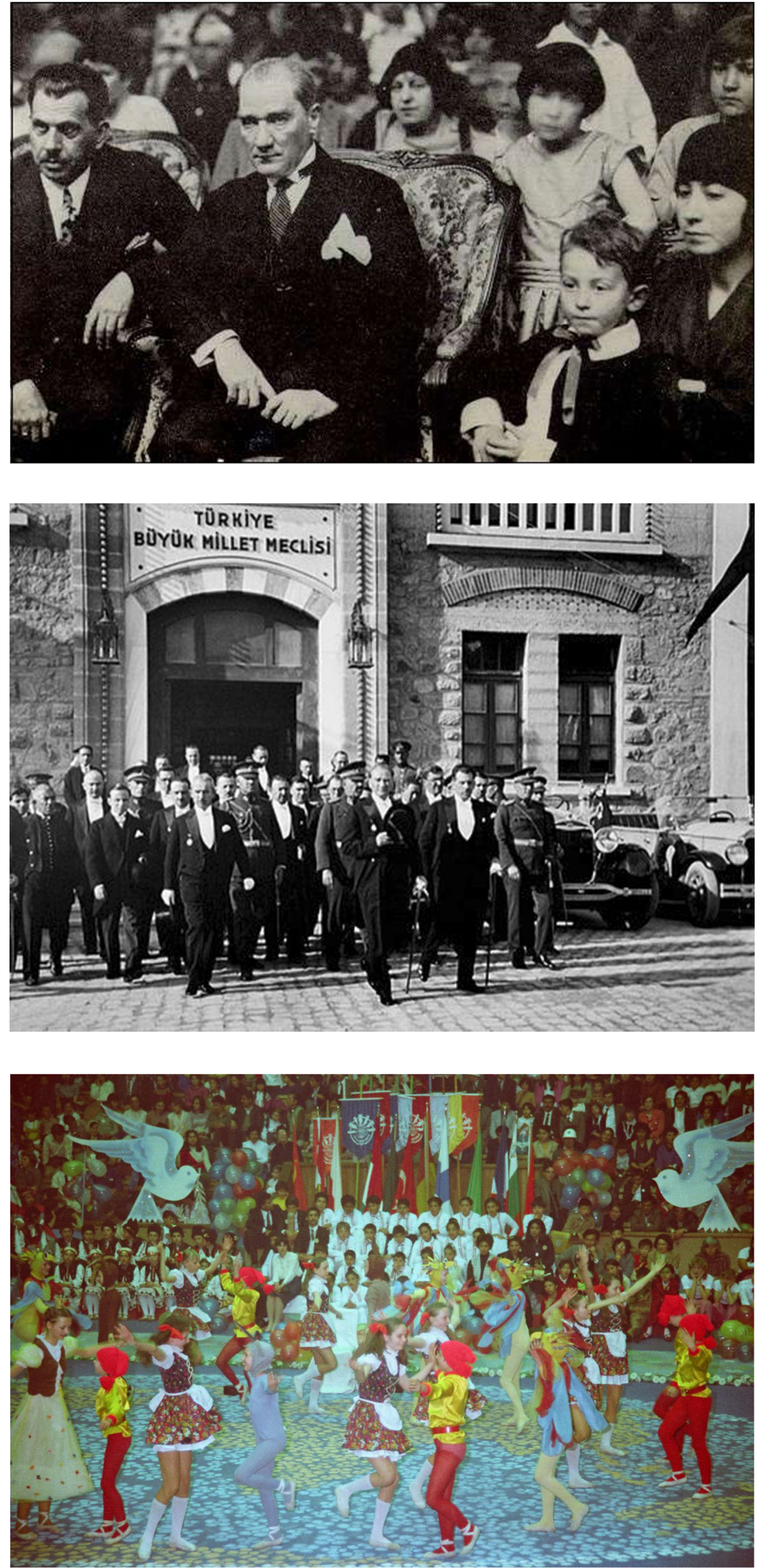
Fig. 4 A photograph of ceremony of 800 children from a total of 40 countries of the world on the National Sovereignty and Children's Day at Ankara, Turkey in 2019, with written permission of the authority of the Turkish Radio and Television Corporation (https://www.trthaber.com/haber/ turkiye/40-ulkeden-800-cocuktrtnin-duzenledigi-senliktebulustu-412004.html)

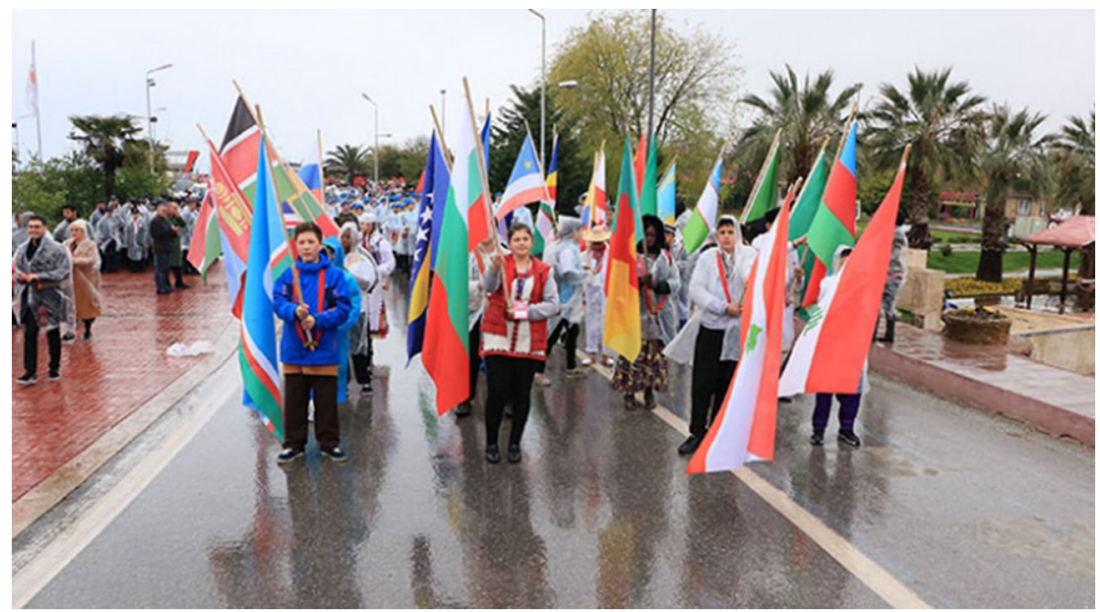

\section{Compliance with ethical standards}

Conflict of interest The authors declare that they have no conflict of interest.

\section{References}

1. Alaranta T (2008) Mustafa Kemal Atatürk's six-day speech of 1927: defining the official historical view of the foundation of the Turkish Republic. Turkish Studies 9:115-129
2. Atatürk MK (2008) The great speech. Atatürk Research Center, Ankara

3. Mango A (2000) Atatürk: the biography of the founder of modern Turkey. London: John Murray, 1999; Woodstock, NY: Overlook Press, pp. 687

Publisher's note Springer Nature remains neutral with regard to jurisdictional claims in published maps and institutional affiliations. 